\title{
A pockmark field in the Central Barents Sea; gas from a petrogenic source?
}

\author{
ANDERS SOLHEIM AND ANDERS ELVERHØI
}

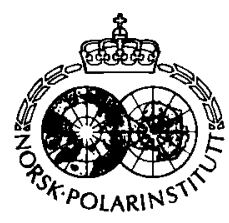

\begin{abstract}
Solheim, A. \& Elverhøi, A. 1985: A pockmark field in the Central Barents Sea; gas from a petrogenic source? Polar Research 3 n.s., 11-19.

A pockmark field has been encountered in the northwestern Barents Sea, $50 \mathrm{~km}$ southeast of Hopen island. High resolution seismic records and side scan sonographs show that the features are small $(10-20 \mathrm{~m}$ diameter), shallow ( $<1 \mathrm{~m}$ deep) structures that may cover up to $25 \%$ of the sea floor in local areas. Pockmark existence seem to be dependent on the presence of soft, Holocene mud. In more firm sea-floor they seem to concentrate in the partly infilled troughs of iceberg plough marks. The pockmark distribution, characteristics of the underlying sedimentary bedrock and thin cover of glacigenic sediments in the area, indicate they are formed by ascending gas from a deeper, probably petrogenic source. It is inferred that pockmarks may be found in larger parts of the Barents Sea.
\end{abstract}

Anders Solheim and Anders Elverhøi, Norwegian Polar Research Institute, Rolfstangveien 12, 1330 Oslo Lufthavn, Norway; April 1984 (revised September 1984).

\section{Introduction}

Pockmarks are circular to oval depressions in the sea floor (Hovland 1981a). They were first described by King \& MacLean (1970) from the Scotian shelf, and are later reported from a number of shelf areas throughout the world (Fannin 1980). In the North Sea, pockmarks are abundant, especially in the deeper waters of the Norwegian Channel (Van Weering et al. 1973; McQuillin et al. 1979; Maisey et al. 1980; Hovland 1981a, b; Van Weering 1982). Size and shape of the features may vary. Reported diameters vary from 10 to $400 \mathrm{~m}$, with an average of $50-90 \mathrm{~m}$, while depth ranges from 2 to $15 \mathrm{~m}$, with an average of $4-6 \mathrm{~m}$. Where the pockmarks are elongated, they tend to have a preferred long axis orientation along the prevailing bottom current direction (Fannin 1980; King 1980). Pockmarks may appear as single features, as groups or as longer chains. In the latter case, there are often a large "parental" pockmark associated with a chain of smaller ones (Hovland 1981a).

Origin of pockmarks is still a disputed subject, but most workers now agree that they are escape phenomena of gas or liquid from the sediment. Fine-grained sediment will, by this process, be brought into suspension and transported away with currents. This explains a preferred orienta- tion of pockmarks, and also the lack of a rim around most of the depressions (King \& McLean 1970; McQuillin et al. 1979). The most widely accepted view is that the escaping medium is gas, either from an underlying petrogenic source, or formed by decay of organic matter in the sediments as biogenic gas. The two may be distinguished from the ratio of light to heavy hydrocarbons and the $C$ values (Cline \& Holmes 1977; Nelson et al. 1978; Nelson et al. 1979; Faber \& Stahl 1984). Gas may also exist as gas hydrate (Kvenvolden 1982) before it is released through the sediment due to decomposition of the hydrate. In the case of liquid, water is the most likely medium. There are clear indications that pockmarks in the Baltic Sea have been formed by freshwater seepage through artesian aquifers (Whiticar \& Werner 1981). Another possibility mentioned in the literature is melting of deeper lying permafrost (Fannin 1980). Since pockmarks in the northern regions seem to be confined to areas of late glacial and Holocene soft mud as surficial sediment (Fannin 1980), it appears likely that the existence of cohesive, fine grained sediment is important for the preservation of the features.

Up until now, there has been no reports of pockmarks in the Barents Sea, north of $72^{\circ} \mathrm{N}$. This is most likely due to the fact that no side 
LOCATION MAP Contour interval 100 metres

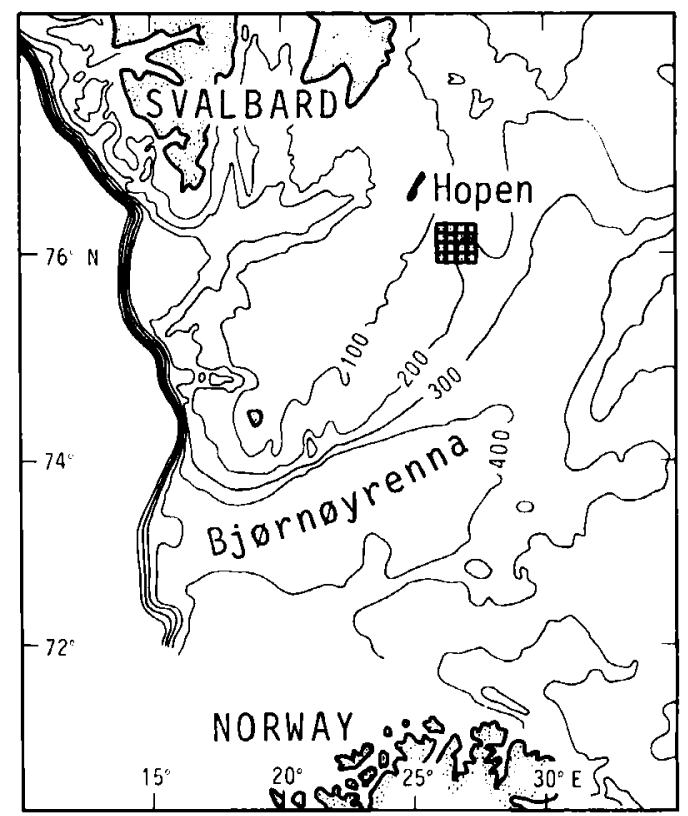

Fig. 1. The survey area. Contours are bathymetry in metres. Numbers along ship tracks are relative pockmark abundance, averaged over a window of $200 \times 500$ metres. Stippled lines mark boundaries between surface sediment types as mapped by Elverhøi \& Solheim (1983c); SGM: sandy gravelly mud, MS \& G: muddy sand and gravel, $M$ \& SM: mud/sandy mud. Figure numbers refer to other illustrations in the text.

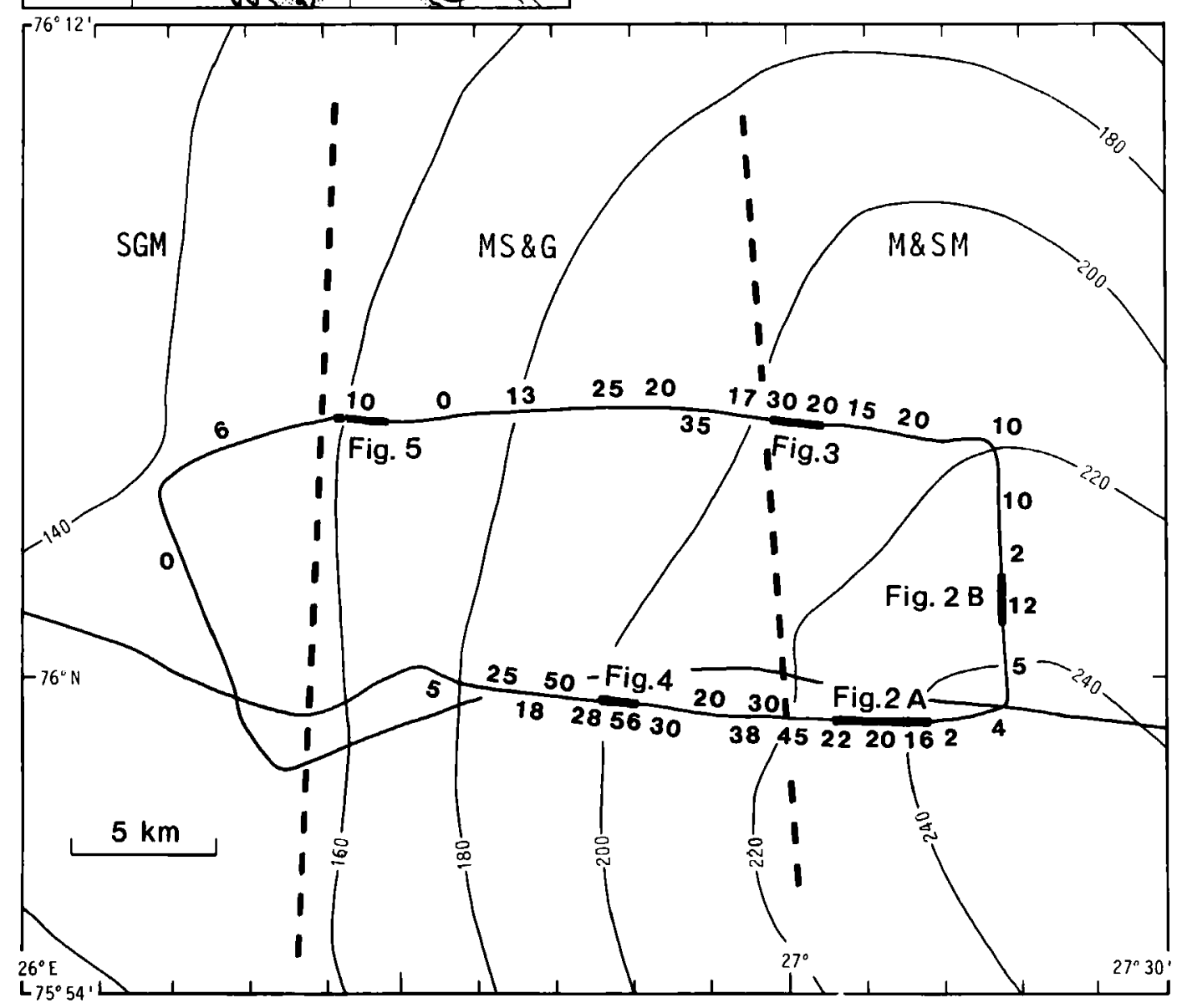


A)

W

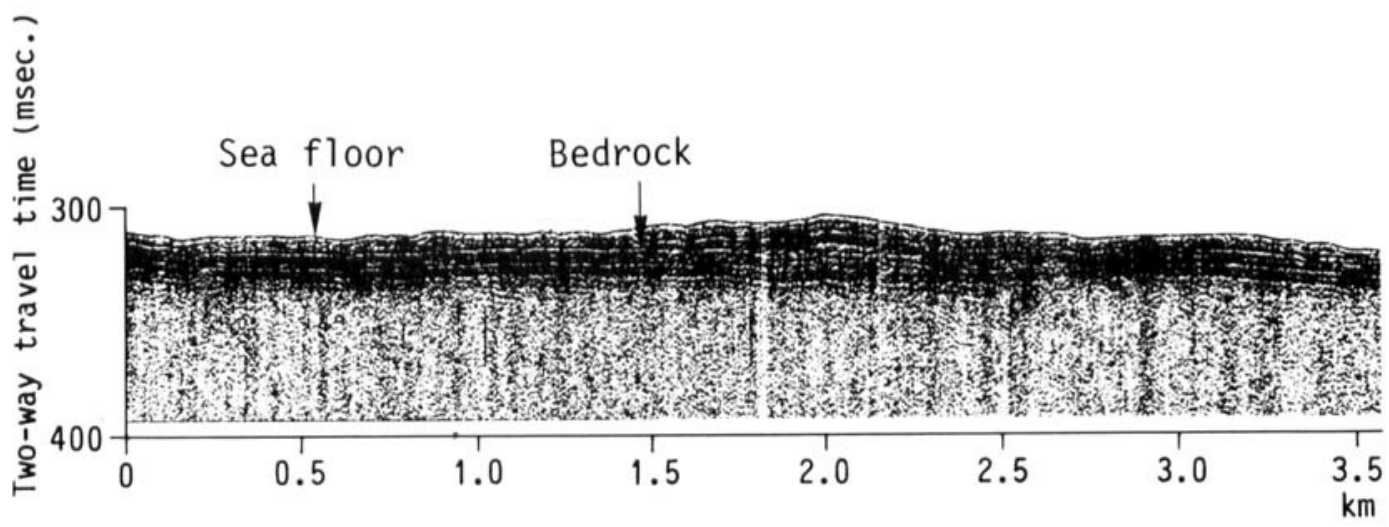

B )

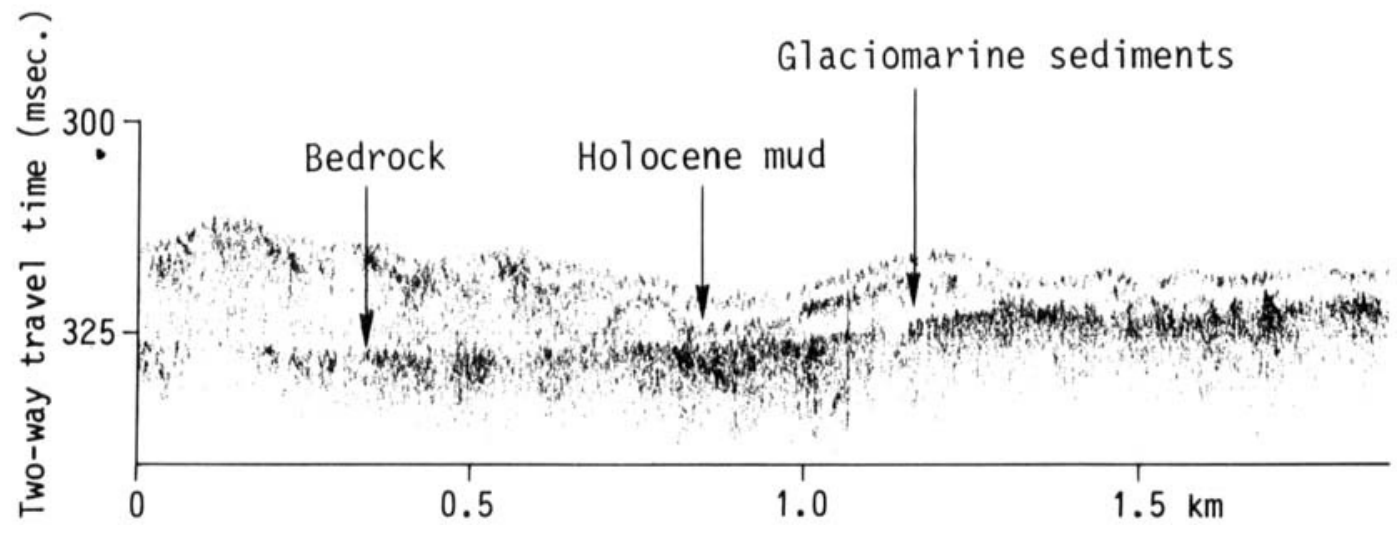

Fig. 2. A. $1 \mathrm{~kJ}$ multielectrode sparker profile showing the thin cover of unconsolidated sediments and the sub-conformable bedrock surface. B. $3.5 \mathrm{kHz}$ PDR record from the eastern part of the survey area. This part has sparse pockmark abundance, but relatively thick unconsolidated deposits. For location, see Fig. 1.

scan sonar work has been done in the area. During a marine geological/geophysical cruise in 1983 (Elverhøi \& Solheim 1983a), a Klein side scan sonar system $(50 \mathrm{kHz}$ transducers) was operated in conjunction with a $1 \mathrm{~kJ}$ multielectrode sparker and a $3.5 \mathrm{kHz}$ precision depth recorder (PDR) over the northern part of the Bjørnøyrenna deep trough (Fig. 1). Here an area of pockmarks was encountered at water depths ranging from $130 \mathrm{~m}$ to $240 \mathrm{~m}$.

\section{Geological setting}

The surveyed area (Fig. 1) is situated approximately $50 \mathrm{~km}$ southeast of the island Hopen in the Svalbard Archipelago, on the northeasterly running slope between the shallow bank area Spitsbergenbanken (waterdepth $<50 \mathrm{~m}$ ) and Bjørnøyrenna (waterdepth $>300 \mathrm{~m}$ ). $3.5 \mathrm{kHz}$ PDR and sparker records obtained during this survey, indicate an upper sediment layer with 


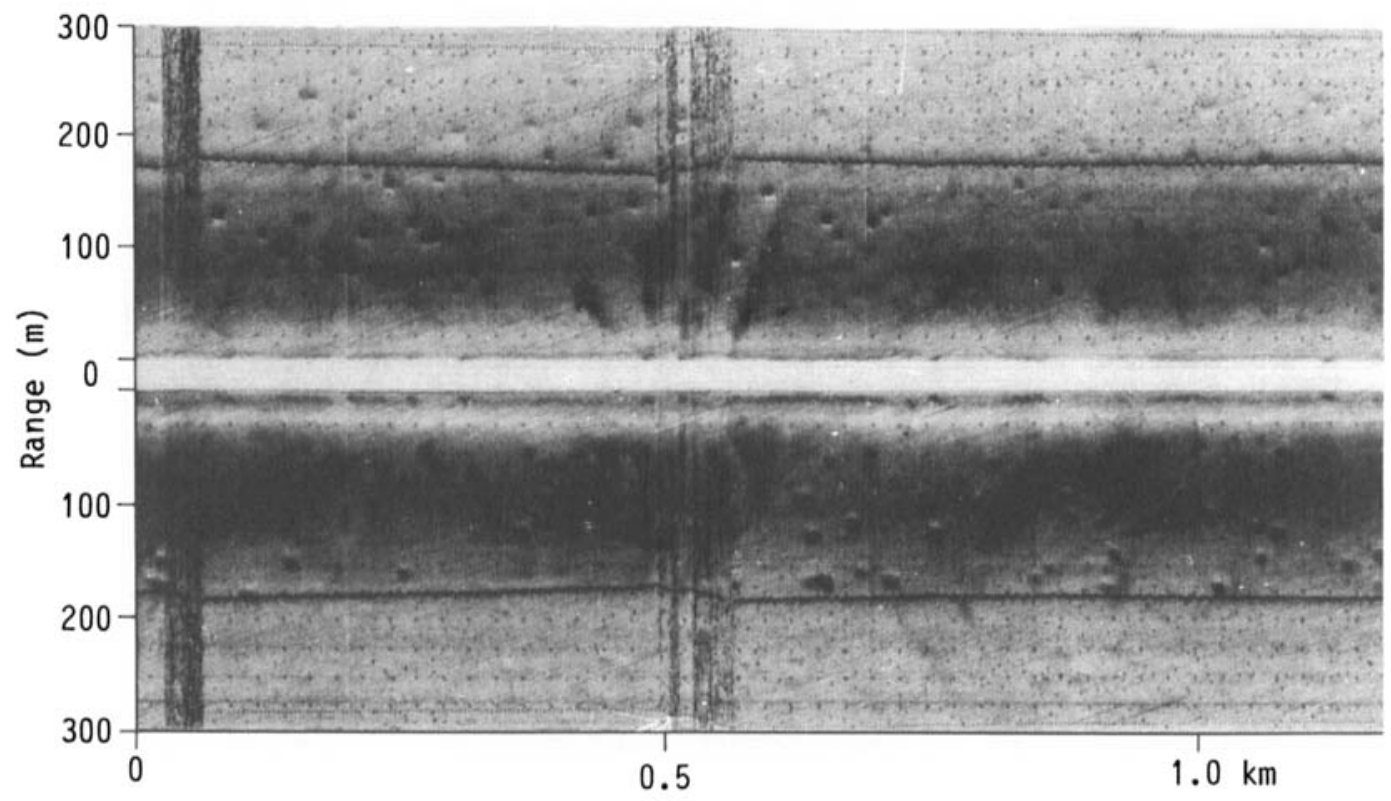

W

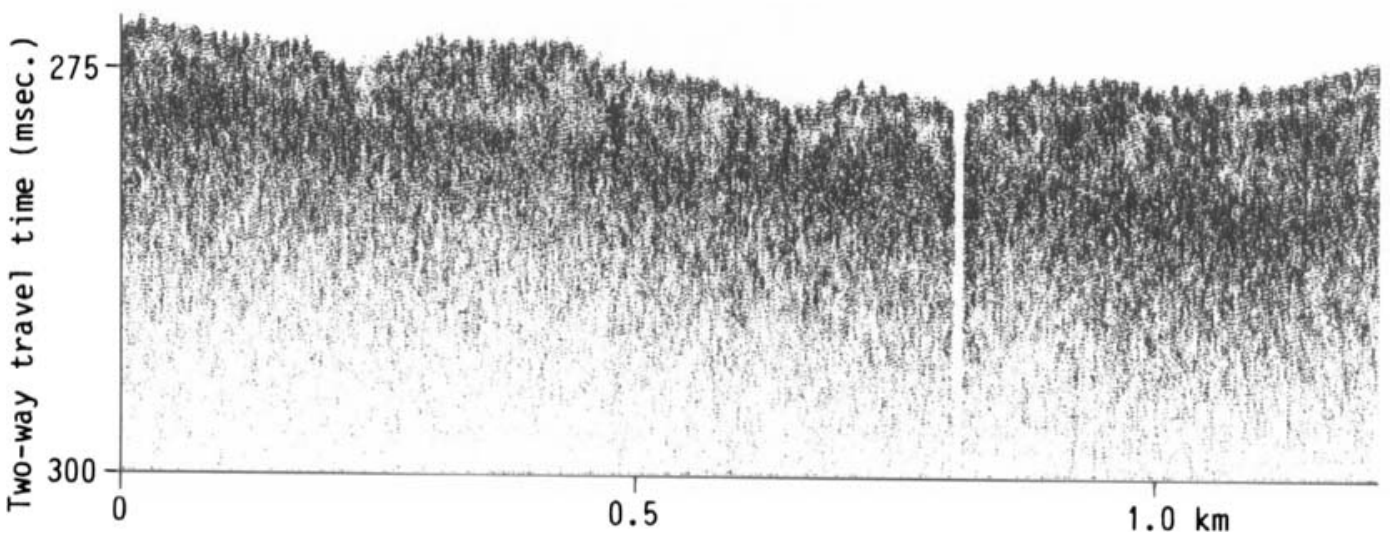

Fig. 3. Side scan sonograph (upper) and $3.5 \mathrm{kHz}$ PDR (lower) record of an area with average pockmark abundance and some iceberg plough marks. For location, see Fig. 1.

thickness generally less than the sparker pulse length of 10-15 milliseconds (msec.) (Fig. 2A). The general Quaternary sequence in the northern Barents Sea (Elverhøi \& Solheim 1983b) is till (probably of Late Weichselian age) overlain by glaciomarine sediments, with a cover of Holocene mud in deeper areas (Fig. 2B). According to Elverhøi \& Solheim (1983c), surface sediments in the area vary from a sandy, gravelly mud in the western, shallowest part, through muddy sand and gravel in central parts, to mud/sandy mud in the eastern, deepest part (Fig. 1). The mud/sandy mud in the eastern part of the survey area should represent the Holocene soft mud. The sample density of Elverhøi \& Solheim (1983c) in this particular area is, however, sparse and the high 


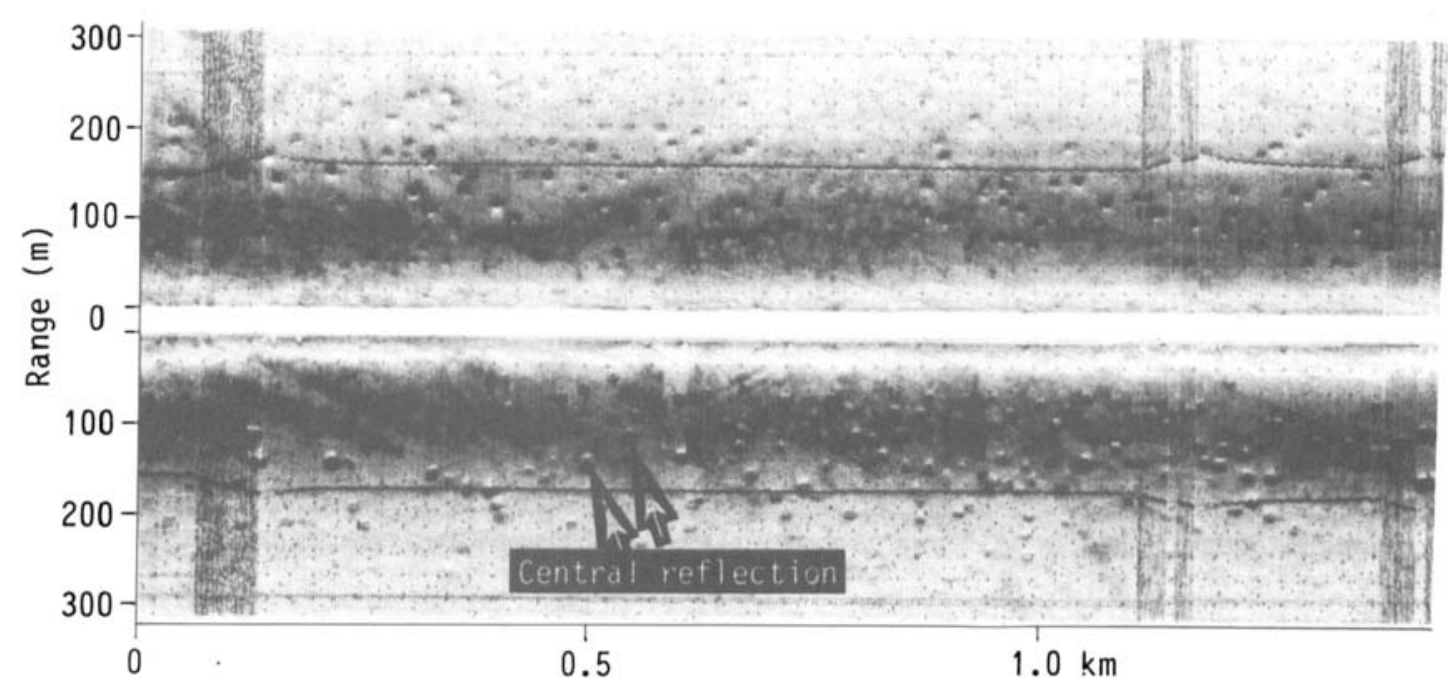

W

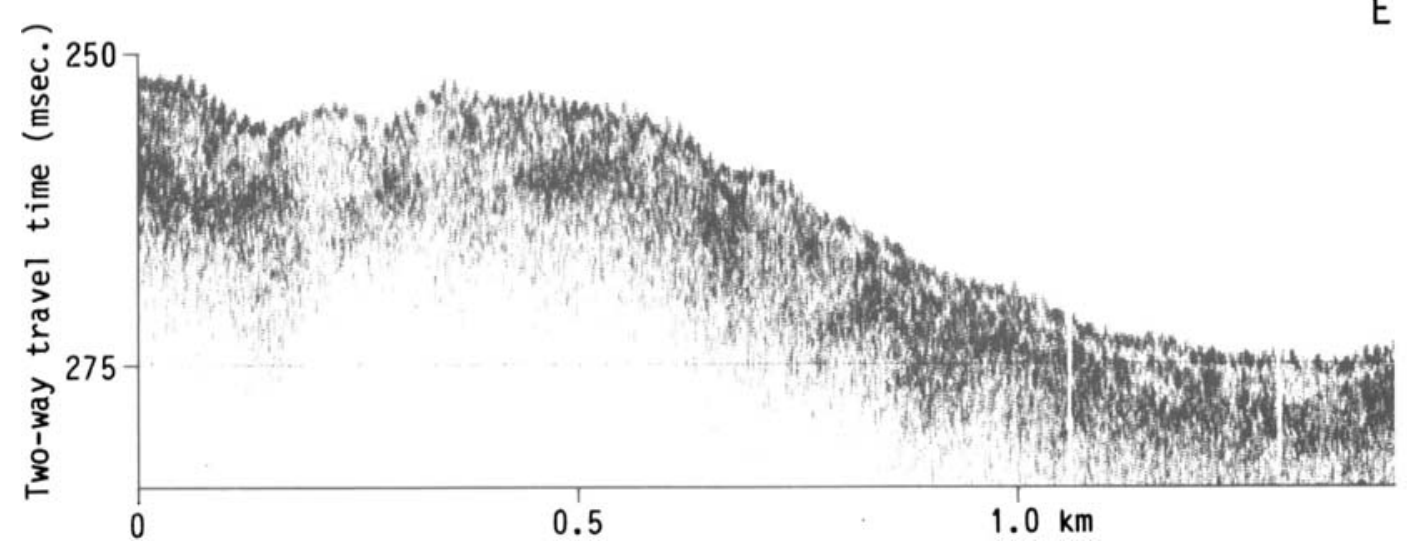

Fig. 4. Side scan sonograph (upper) and $3.5 \mathrm{kHz}$ PDR (lower) record of an area with high pockmark abundance. Note central reflection in several of the depressions. For location, see Fig. 1.

frequency records obtained during the 1983 survey indicate that the soft mud blanket may continue further to the west than indicated in Fig. 1. It also seems to exist in local depressions, like plough marks, in the westernmost part of the survey area.

The underlying bedrock is apparently sub-conformable with the sea floor in this part of the Barents Sea (Solheim \& Kristoffersen 1984). Based on dredged rock samples, the bedrock is interpreted to be of Triassic age (Bjærke 1979; Dibner et al. 1981; Elverhøi \& Lauritzen 1984), which is also in accordance with results from seismic exploration surveys (Rønnevik \& Motland 1979). Furthermore, the bedrock on Hopen is Triassic shales, silt- and sandstones (Flood et al. 1971; Smith et al. 1975; Winsnes \& Worsley 1981).

\section{Size and distribution of pockmarks in the surveyed area}

Pockmarks encountered in the survey area are relatively small compared to what is described 

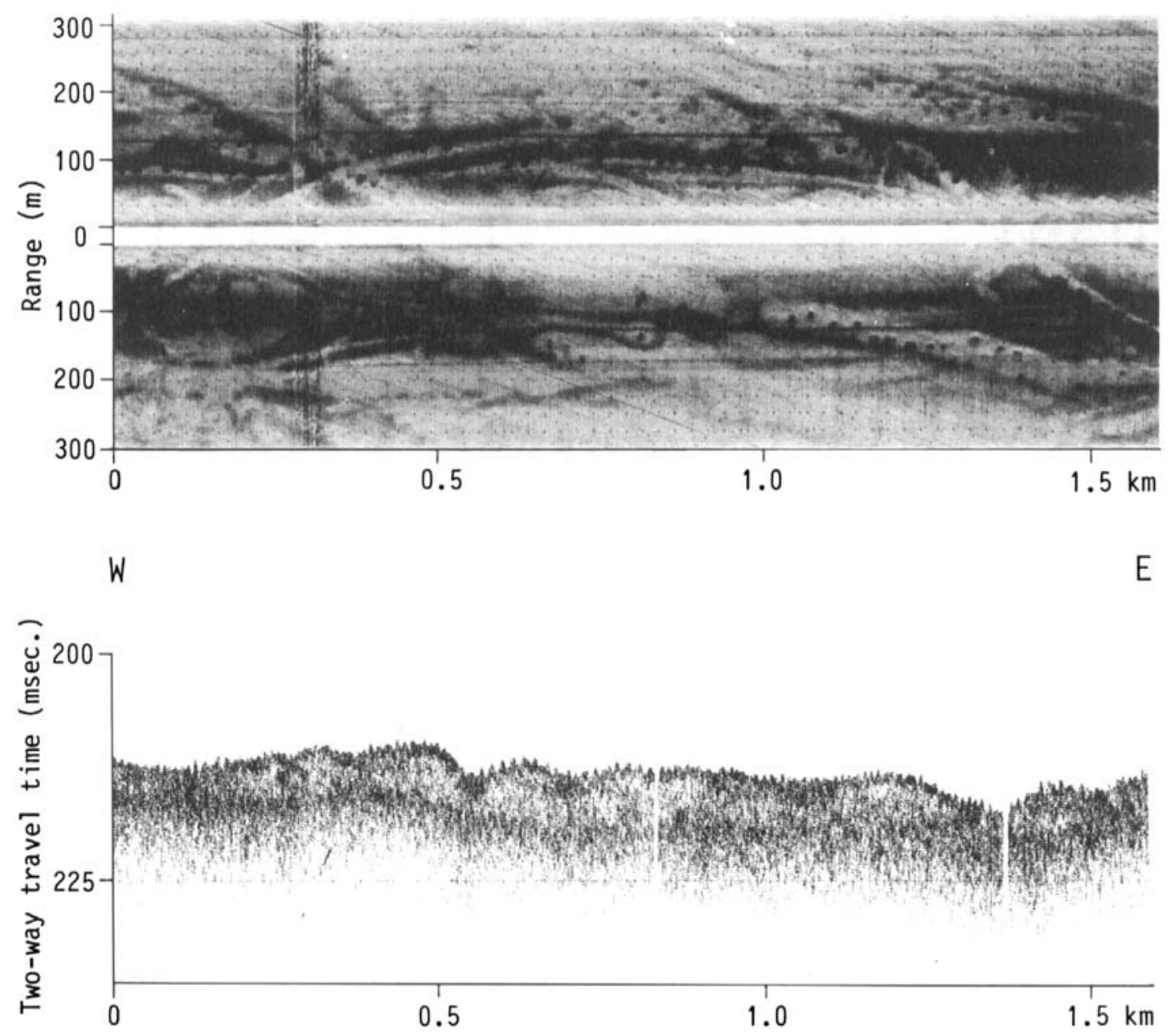

Fig. 5. Side scan sonograph (upper) and $3.5 \mathrm{kHz}$ PDR (lower) record from an area with pockmark concentrations in the troughs of iceberg plough marks. For location, see Fig. 1.

from Canadian and Norwegian shelf areas (Josenhans et al. 1978; Hovland 1981a, b). They are, however, comparable both in size (somewhat larger) and relative abundance to pockmarks described from the Bering shelf (Nelson et al. 1979). The features are semicircular shape, with a typical diameter of $10-20 \mathrm{~m}$ (Fig. 3), always less than $25 \mathrm{~m}$. They may coalesce to form larger features, but still individual pockmarks may be identified. The relative abundance varies from a few scattered pockmarks to a density where they locally cover approximately $25 \%$ of the sea floor (Fig. 4).

The pockmarks also appear to be shallow struc- tures. They can not be resolved by the $3.5 \mathrm{kHz}$ PDR records (Fig. 3), nor do they appear to give rise to any diffraction patterns, although the record quality is obscured by a $2-3 \mathrm{~m}$ swell. The size of the shadow zone, generated on the side scan sonographs by the edge of the pockmarks, indicate depths of less than one meter. A number of pockmarks are also barely visible on the records. From the side scan sonographs, there appear to be no raised sediment rim around the pockmarks. However, some of them have a central reflection (Fig. 4), which may be caused either by a small high within the pockmarks, or from accumulation of coarser material causing higher 
reflectivity in the centre of the depressions. As no distinct shadow behind the reflection is seen, the latter explanation is favoured here.

The pockmarks first appear below a water depth of approximately $130 \mathrm{~m}$, but any correlation of pockmark abundance with waterdepth seems to be a function of the existence/nonexistence of a top layer of soft mud. At shallower waterdepth, the bottom is harder and rougher with no apparent pockmarks. Inside the area where pockmarks do occur, the relative density is sparse to average (2-12 pockmarks inside a window of $200 \times 500 \mathrm{~m}$ ) (Fig. 1) in the deepest areas, while at two places, with intermediate waterdepths, the abundance increases up to a $25 \%$ coverage of the sea floor (relative number inside same window is greater than 50). Both these locations have steeper sloping sea-floor relative to the adjacent areas (Fig. 4).

Within the rather narrow range of sediment thicknesses in the surveyed area $(2-15 \mathrm{msec}$., average $7-8 \mathrm{msec}$.), there seems to be no correlation between pockmark abundance and sediment thickness. The locations of highest pockmark abundance has a thinner sediment cover than that found in the eastern part (Fig. 2B) of the area. In the western part of the survey area where frequency of iceberg plough marks increases and both side scan sonographs and $3.5 \mathrm{kHz}$ records indicate harder sea-floor, pockmarks seem to be concentrated in the troughs of iceberg plough marks (Fig. 5).

Variation in size of the individual pockmarks is also small. However, there may be a slight increase in average size with increasing relative abundance.

\section{Discussion}

Provided the pockmarks are formed by ascending gas, it may be debated whether the gas is biogenic, formed by decay of organic matter in the sediments above bedrock, or is of petrogenic origin, leaking from a deeper source.

Several lines of evidence suggest that the formation of enough biogenic gas to form sea-floor craters is unlikely, and thus that the pockmarks in the surveyed area are formed by ascending petrogenic gas.

1. The cover of Quaternary sediment is sparse, seldom exceeding $10 \mathrm{msec}$. (two-way travel time).

2. The Late Weichselian glaciomarine sediments, which comprise the major part of the Quarternary cover in the area, have a total carbon content seldom exceeding $1-2 \%$, which almost exclusively consists of redeposited coal fragments. Primary organic carbonaceous matter is only found in the top, Holocene mud (Forsberg 1983).

3. Underlying bedrock is a sedimentary sequence of Mesozoic, probably Triassic age. Layers of carbonaceous and coaly shales are present within the Triassic succession on Hopen (Flood et al. 1971; Smith et al. 1975). In the Triassic Sassendalen Group, total organic carbon values ranging up to $10 \%$, have been measured on eastern Spitsbergen, Barentsøya and Edgeøya (Mørk et al. 1982). Bjorøy et al. (1983) state a source rock potential for oil and gas in Triassic shales of Bjørnøya as well as in the submarine parts of the Barents Shelf (from surface samples).

4. Higher relative abundance of pockmarks apparently independent of sediment thickness and waterdepth may indicate zones of increased permeability to gas leakage. Since the zones of high pockmark abundance are located at sites of increased sea-floor slope, and the underlying bedrock layers in general are sub-conformable with the sea floor, these zones could be related to outcropping layers of sedimentary rocks underneath the Quaternary cover. It should, however, be stressed that the data is limited and only from a single area. Significant correlations can only be made with more data, covering a larger area.

A water seepage origin for the pockmarks similar to the artesian aquifers described from the Baltic Sea (Whiticar \& Werner 1981) is unlikely in this area. Any potential source land areas, which are considerably further away than was the case in the Baltic Sea, are permafrost areas, with little possibility of precipitation reaching aquifers. Considering melting of subsea permafrost as a mode of pockmark formation, permafrost in the unconsolidated sediments can be excluded, as the major part consists of glaciomarine sediments, deposited shortly after the retreat of the Late Weichselian ice sheet (Elverhøi \& Solheim 1983b). Any cover of till below the glaciomarine sediments is either very thin or absent. Low porosities $(2.5-5 \%)$ and high seismic velocities $(3.5-4.5 \mathrm{~km} / \mathrm{s})$ measured in southeastern Svalbard and adjacent parts of the Barents Sea (Eldholm \& Talwani 1977; Elverhøi \& Grønlie 1981) also 
make melting of deeper permafrost in the sedimentary rocks an unlikely explanation.

Thus, assuming ascending gas as the most likely mode of formation, the possibility of gas hydrate should be considered. To-day's temperature and depth conditions (Pfirman 1984) are marginal for gas hydrate formation (Weaver \& Stewart 1982), and no Bottom-Simulating Reflector (BSR) has been observed in any of the seismic records. Thus existence of gas hydrates to-day is considered unlikely. However, gas hydrates formed during the Late Weichselian when the area probably was ice covered (Elverhøi \& Solheim 1983b), and now fully decomposed, can not be excluded.

As observed by Hovland (1981a) in the North Sea, formation and preservation of pockmarks are closely related to sediment type. A soft, fine-grained sediment is necessary as recording medium. In the Barents Sea, this is clearly demonstrated in the area with higher iceberg plough mark frequency. The plough marks are relict features, most likely dating back to early post Late Weichselian (Elverhøi \& Solheim 1983c; Lien 1983). In the troughs there has probably been deposition of fine-grained sediment through the Holocene, and this is the most likely reason for the pockmark concentrations in the plough marks. The ploughmarks are cut in glaciomarine sediments interpreted to be of Late Weichselian age (Elverhøi \& Solheim 1983b). This and the gross distribution of pockmarks indicate that pockmark formation and preservation in the survey area is dependent on existence of a Holocene top layer, analogous to that found on the Scotian shelf (King \& MacLean 1970). In the latter area pockmarks are related to the LaHave Clay, a Holocene deposit formed by winnowing and redeposition of glacial sediments from shallower banks.

Due to the low undrained shear strengths in the Holocene and glaciomarine sediments in the study area $(<10 \mathrm{kPa})$, it appears unlikely that high enough gas pressures could build up to cause catastrophic events, as was also proposed for the North Sea by Fannin (1980). Formation by intermittent low pressure emissions over a period of time seems more likely. This is also consistent with the interpreted mode of formation of the central reflection. As the content of gravel is less than $5 \%$ in the Holocene mud (Elverhøi \& Solheim 1983c), most of the material causing higher reflectivity is probably sand/silt-sized, concentrated through gradual removal of finer material.
The acoustic records do not give any indications of gas migration paths, like sediment disturbances or faults (Hovland 1983). The glaciomarine sediments sampled in adjacent areas are probably too soft to sustain any fissure system, and in the underlying overconsolidated material, the sample control is too poor. However, these sediments have a sand/silt content ranging up to $75 \%$ (Elverhøi \& Solheim 1983b), which may make them permeable enough for slow, vertical gas migration.

Regardless of the mode of formation, however, pockmarks do affect sea-floor stability, and detailed mapping of this, at least locally, common feature is therefore of importance for offshore construction work. Extrapolating from the survey area to the rest of the Barents Sea, both the subsurface and the sea floor point towards existence of pockmarks in larger parts of the Barents Sea, especially in deeper waters where the surface sediment most commonly consists of Holocene mud. However, in the southern Barents Sea (south of approximately $74^{\circ} \mathrm{N}$ ), the total thickness of sediments above bedrock may attain considerable thickness (Solheim \& Kristoffersen 1984). In these areas, the possibility of biogenic gas formation within the sediments may be higher.

\section{Conclusions}

A local survey $50 \mathrm{~km}$ southeast of Hopen shows that:

- Pockmarks exist and are locally abundant on the floor of the Barents Sea. In the survey area they are semicircular, small $(10-20 \mathrm{~m}$ diameter) and shallow $(<1 \mathrm{~m})$ structures. They do not show any trend in orientation, but the areas of highest relative abundance coincide with areas of somewhat steeper dipping sea floor and possibly outcropping sedimentary bedrock layers.

- The pockmark distribution, characteristics of the underlying bedrock, and the thin cover of glacigenic sediments strongly suggest ascending petrogenic gas from a deeper source as the mode of formation.

- There are indications that pockmarks are confined to areas where the top sediment consists of soft, Holocene mud.

- Sea floor conditions are similar to those of the survey area over large parts of the Barents Sea, and it is likely that pockmarks occur over larger areas. 
Acknowledgements. - The data base for this research was collected during a joint cruise between the Norwegian Polar Research Institute, the Norwegian Petroleum Directorate, and the Woods Hole Oceanographic Institution. Nigel Fannin, Yngve Kristoffersen, and Tom Bugge are acknowledged for critical comments on the manuscript. We are grateful to Captain Terje Langvik and his crew aboard the $\mathrm{R} / \mathrm{V}$ "Lance" for their valuable cooperation in the field. ARCO Norway Inc. provided financial support for data analyses.

\section{References}

Bjorøy, M., Mørk, A. \& Vigran, J. O. 1983: Organic geochemical studies of the Devonian to Triassic succession on Bjørnøya and the implications for the Barents Shelf. Advances in Organic Geochemistry 1981, 49-59. John Wiley \& Sons, Ltd.

Bjærke, T. 1979: Geology of the Barents Sea shelf; evidence from palynological studies of drift material. Proc. of Norwegian Sea Symposium, Troms $\emptyset$ 1979, 17/1-17/15.

Cline, J. D. \& Holmes, M. L. 1977: Submarine seepage of natural gas in Norton Sound, Alaska. Science 198, 1149-1153.

Dibner, A. F., Dibner, V. D., Korotkevic, V. D. \& Lodkina, L. B. 1981: Carboniferous, Permian and Triassic palynocomplexes of the Barents Shelf and their geological significance. Geology and Mineralogy of the Arctic Area of the USSR. Collection of Scientific Papers, 49-63.

Eldholm, O. \& Talwani, M. 1977: Sediment distribution and structural framework of the Barents Sea. Geol. Soc. Am. Bull. 88, 1015-1029.

Elverhøi, A. \& Grønlie, G. 1981: Diagenetic and sedimentologic explanation for high seismic velocity and low porosity in Mesozoic-Tertiary sediments, Svalbard region. Am. Ass. Petr. Geol. Bull. 65, 145-153.

Elverhøi, A. \& Lauritzen, $\emptyset$. 1984: Bedrock geology of the northern Barents Sea (west of $35^{\circ} \mathrm{E}$ ) as inferred from the overlying Quaternary deposits. Nor. Polarinst. Skr. 180.

Elverhøi, A. \& Solheim, A. 1983a: Marin-geologiske og -geofysiske undersøkelser i Barentshavet 1983. Toktrapport. Nor. Polarinst. Rapportserie 14, $116 \mathrm{pp}$.

Elverhøi, A. \& Solheim, A. 1983b: The Barents Sea ice sheet - a sedimentological discussion. Polar Research 1 n.s., 23-42

Elverhøi, A. \& Solheim, A. 1983c: The physical environment, Western Barents Sea, $1: 1,500,000$, sheet A; surface sediment distribution. Nor. Polarinst. Skr. 179 A. 23 pp.

Faber, E. B. \& Stahl, W. 1984: Geochemical surface exploration for hydrocarbons in the North Sea. A.A.P.G. Bull. 68, 363-386.

Fannin, N. G. T. 1980: The use of regional geological surveys in the North Sea and adjacent areas in the recognition of offshore hazards. Pp. 5-22 in Ardus, D. A. (ed.): Offshore sire investigation. Graham \& Trotman Publishers, London.

Flood, B., Nagy, J. \& Winsnes, T. S. 1971; The Triassic succession of Barentsøya, Edgeøya and Hopen (Svalbard). Nor. Polarinst. Medd. $100.24 \mathrm{pp}$.

Forsberg, C. F. 1983: Sedimentation and early diagenesis of late Quaternary deposits in the central Barents Sea. Unpubl. thesis, Univ. of Oslo.

Hovland, M. 1981a: Characteristics of pockmarks in the Norwegian Trench. Marine Geology 39, 103-117.

Hovland, M. 1981b: A classification of pockmarks related features in the Norwegian Trench. Continental Shelf Institute, Norway, Publ. 106. 28 pp.
Hovland, M. 1983: Elongated depressions associated with pockmarks in the western slope of the Norwegian Trench. Marine Geology 51, 35-46.

Josenhans, H. W., King, L. H. \& Fader, G. B. 1978: A sidescan sonar mosaic of pockmarks on the Scotian shelf. Can. J. Earth Sci. 15, 831-840.

King, L. H. 1980: Aspects of regional surficial geology related to site investigation requirements - Eastern Canadian shelf. Pp. 37-59 in Ardus, D. A. (ed.): Offshore site investigation. Graham \& Trotman Publishers, London.

King, L. H. \& MacLean, B. 1970: Pockmarks on the Scotian shelf. Geol. Soc. Am. Bull. 81, 3141-3148.

Kvenvolden, K. A. 1982: Occurrence and origin of marine gas hydrates. Proc. 4th. Can. Permafrost Conf., 305-311.

Lien, R. 1983: Pløyemerker etter isfjell på norsk kontinentalsokkel. Continental Shelf Institute, Norway, Publ. 109. 147 pp.

Maisey, G. H., Rokoengen, K. \& Raaen, K. 1980: Pockmarks formed by seep of petrogenic gas in the southern part of the Norwegian Trench? Continental Shelf Institute, Norway, Rep. P.258.

McQuillin, R., Fannin, N. G. T. \& Judd, A. 1979: IGS pockmark investigations 1974-1978. Inst. of Geol. Sciences, Cont. Shelf Div., Marine Geophysics Unit, Rep. $98.50 \mathrm{pp.}$

Mørk, A., Knarud, R. \& Worsley, D. 1982: Depositional and diagenetic environments of the Triassic and lower Jurassic succession of Svalbard. Pp. 371-398 in Embry, A. F. \& Balkwill, H. R. (eds.): Arctic geology and geophysics. Can. Soc. Petroleum Geol. Mem. 8, 371-398.

Nelson, H., Kvenvolden, K. A. \& Clukey, E. C. 1978: Thermogenic gases in near-surface sediments of Norton Sound, Alaska. Proc. Offshore Tech. Conf., OTC-3354, 2623-2633.

Nelson, H., Thor, D. R., Sandstrom, M. W. \& Kvenvolden, K. A. 1979: Modern biogenic gas-generated craters (sea-floor "pockmarks") on the Bering shelf, Alaska. Geol. Soc. Am. Bull. 90. 1144-1152.

Pfirman, S. L. 1984: Water masses of the northern Barents Sea. Woods Hole Oceanographic Institution, Unpubl. Ph.D. thesis. 19-58.

Rønnevik, H. C. \& Motland, K. 1979: Geology of the Barents Sea. Norwegian Sea Symposium, Troms 1979, 15/1-15/34.

Smith, D. G., Harland, W. B. \& Hughes, N. F. 1975: Geology of Hopen, Svalbard. Geological Magazine 112, 1-23.

Solheim, A. \& Kristoffersen, Y. 1984: The physical environment, Western Barents Sea, $1: 1,500,000$, sheet B; Sediments above the upper regional unconformity: thickness, seismic stratigraphy and outline of the glacial history. Nor. Polarinst. Skr. 179 B. 26 pp.

Van Weering, T. 1982: Shallow seismic and acoustic reflection profiles from the Skagerak; implications for recent sedimentation. Proc. K. Nederlandse Akademie van Wetenschappen, Amsterdam B 85 (2), 129-154.

Van Weering, T., Jansen, J. H. F. \& Eisma, D. 1973: Acoustic reflection profiles of the Norwegian Channel between Oslo and Bergen. Netherlands Journal of Sea Research 6, 241-263.

Weaver, J. S. \& Stewart, J. M. 1982: In situ hydrates under the Beaufort Sea shelf. Proc. 4th. Can. Permafrost Conf. 312-319.

Whiticar, M. J. \& Werner, F. 1981: Pockmarks: Submarine vents of natural gas or freshwater seeps? Geo-Marine Letters 1, 193-199.

Winsnes, T. S. \& Worsley, D. 1981: Geological map, Svalbard 1:500,000, Sheet 2G; Edgeøya. Nor. Polarinst. Skr. 154B. (Map with description). 